Abstracta Iranica Abstracta Iranica

Revue bibliographique pour le domaine irano-aryen

Volume 25 | 2004

Comptes rendus des publications de 2002

\title{
Statistical Center of Iran. Socio-Economic Characteristics of Women in Iran 1986-1996. Tehran, SCI, 2001, 329 p.
}

\section{Marie Ladier-Fouladi}

\section{(2) OpenEdition}

1 Journals

Édition électronique

URL : http://journals.openedition.org/abstractairanica/5130

DOI : $10.4000 /$ abstractairanica. 5130

ISSN : 1961-960X

\section{Éditeur :}

CNRS (UMR 7528 Mondes iraniens et indiens), Éditions de l'IFRI

\section{Édition imprimée}

Date de publication : 15 mai 2004

ISSN : 0240-8910

\section{Référence électronique}

Marie Ladier-Fouladi, «Statistical Center of Iran. Socio-Economic Characteristics of Women in Iran 1986-1996. Tehran, SCI, 2001, 329 p. », Abstracta Iranica [En ligne], Volume 25 | 2004, document 315 , mis en ligne le 15 mars 2006, consulté le 25 septembre 2020. URL : http://journals.openedition.org/ abstractairanica/5130 ; DOI : https://doi.org/10.4000/abstractairanica.5130

Ce document a été généré automatiquement le 25 septembre 2020.

Tous droits réservés 


\title{
Statistical Center of Iran. Socio-
} Economic Characteristics of Women in Iran 1986-1996. Tehran, SCI, 2001, $329 \mathrm{p}$.

\author{
Marie Ladier-Fouladi
}

Cet ouvrage a pour objectif de réunir l'ensemble des statistiques et informations existant sur les femmes en Iran depuis 1986. Les principaux thèmes abordés sont la fécondité, la mortalité, la planification familiale, l'alphabétisation et l'éducation, le mariage, l'activité économique, le rôle de la femme comme chef de famille et enfin la participation des femmes dans la sphère politique. L'ouvrage fournit de nombreux tableaux et graphiques utiles pour une étude de genre en Iran au cours des deux dernières décennies.

\section{INDEX}

Thèmes : 12.1. Iran

\section{AUTEURS}

MARIE LADIER-FOULADI

CNRS - Paris 